ISSN: 0213-2079

DOI: http://dx.doi.org/10.14201/shhmo201436327355

\title{
TERTULIA Y MEDIOS CIRCULACIÓN POLÍTICA EN LA ESPAÑA DE FELIPE V: FRAY ANTONIO MACANAZ Y EL OBISPO BELLUGA $(1714-1720)^{1}$
}

Social Gathering and Means of Political Circulation in the Spain of Philip V. Fray Antonio Macanaz and Bishop Belluga (1714-1720)

Francisco PRECIOSO IZQUIERDO

Universidad de Murcia

Correo-e: fpi13824@um.es

RESUMEN: En este texto analizamos las formas de construcción y circulación de representaciones políticas en la sociedad española de comienzos del siglo Xviır. Para ello, profundizamos en la actividad desarrollada por los seguidores que el fiscal general del consejo de Castilla, Melchor Macanaz, reunirá en la ciudad de Murcia acaudillados por su hermano fray Antonio. Estudiamos los medios empleados en la elaboración y puesta en circulación de un discurso propio con el que interpretarán la defenestración de don Melchor (febrero de 1715), función en la que destacarán dos espacios, el convento murciano de Santo Domingo y una tertulia local de ámbito doméstico. La tensa relación mantenida por este colectivo con el obispo

1. Este trabajo ha sido realizado gracias a la concesión de una beca predoctoral por la Fundación Séneca, Agencia de Ciencia y Tecnología de la Región de Murcia (15520/FPI/10). Forma parte de los proyectos de investigación: Nobilitas II-Estudios y base documental de la nobleza del Reino de Murcia, siglos XV-XIX. Segunda fase: análisis comparativos, financiado por la Fundación Séneca, Agencia de Ciencia y Tecnología de la Región de Murcia (15300/PHC/10) y Familias e individuos: Patrones de modernidad y cambio social (siglos XVI-XXI), financiado por el Ministerio de Ciencia e Innovación (HAR2013-48901-C6-1-R)., financiado por el Ministerio de Ciencia e Innovación. 
Belluga dará lugar a un nuevo episodio de instrumentalización inquisitorial para castigar al líder del grupo.

Palabras clave: Tertulia política; Medios de circulación política; Melchor Macanaz; Fray Antonio Macanaz; Luis Belluga y Monacada; Inquisición.

ABSTRACT: In this paper we analyze the ways of construction and circulation of political representations in eighteenth-century spanish society. We deepen in the activity of the group of followers of Melchor Macanaz in the city of Murcia, commanded by his brother Fray Antonio Macanaz. We will study the means for the representation and circulation of discourse with which interpreted the defenestration of Melchor (February, 1715), emphasizing two spaces, the convent of Santo Domingo in Murcia and local gathering. The strained relationship of this group with Bishop Belluga, will result in a new episode of inquisitorial manipulation by which finally punish the group leader.

Key words: Political-Social Gathering; Forms of Political Circulation; Melchor Macanaz; Fray Antonio Macanaz; Luis Belluga y Moncada; Inquisicion.

\section{Historiar la POlítica NO Formal: teRTUlias y CONVENTíCUlOS}

La historia del poder ha conocido una notable ampliación de perspectivas, objetos de estudio y metodologías, fruto en buena medida de la evolución operada en el conjunto de la historiografía y, en especial, en el terreno de la propia historia política. La renovación experimentada por esta última desde la década de los años ochenta del siglo pasado, ha supuesto una valiosa actualización de sus paradigmas y contenidos. Guiada por una actitud abierta a «todo aquello que tenga que ver con el fenómeno del poder» ${ }^{2}$, ha logrado «expandir su territorio en todas las direcciones ${ }^{3}$, lo que ha favorecido, a su vez, la plena aceptación de lo político como categoría válida para aproximarnos al conocimiento y comprensión global de la realidad social del pasado.

2. Remond, R.: Pour une histoire politique. París, 1983, pp. 11-32.

3. Gil Pujol, X.: «La historia política de la Edad Moderna, hoy: progresos y minimalismo», en Barrios, C. (coord.): Historia a debate, vol. III. Santiago de Compostela, 1995, pp. 195-196. 
La nueva mirada de la historia política ha contribuido a fijar una noción mucho más compleja, rica y envolvente del poder ${ }^{4}$. Definido ahora en términos de relación, más que una mera imposición material ${ }^{5}$, la historiografía reciente no ha dejado de advertir el peso de la acción humana en su ejercicio, lo que unido a la utilización de herramientas propias del análisis social, como la prosopografía o las redes sociales, ha permitido la exploración de otras muchas dimensiones no formales del mismo. Se pone de relieve así la transcendencia de aquella otra forma de hacer política dirigida por cauces distintos al escenario oficial, ajena a los grandes organismos, donde los factores de tipo social y personal (clientelismo, parentesco, amistad, paisanaje, etc.) jugaban un papel completamente determinante ${ }^{6}$.

La renovada visión sobre el poder ha servido para reforzar la imagen de una sociedad, la antiguo-regimental, mucho más ágil, dinámica e interaccionada de lo que se había concebido7. Hoy podemos afirmar que la acción política y su repercusión, lejos de la interpretación tradicional (limitada a colectivos minoritarios) llegaba a interesar a un número notable de grupos y personas más allá de espacios como el cortesano o la alta administración, alcanzando en el ámbito local y territorial niveles más amplios de difusión ${ }^{8}$.

Así se ha demostrado, entre otros, con los estudios sobre la incipiente "opinión pública» en los siglos modernos 9 , a partir de los cuales se ha podido comprobar cómo los individuos de entonces también se preocupaban, reunían y chismorreaban entre sí sobre las consecuencias de tal o cual medida política, un ministro controvertido o eventuales cambios en el gobierno ${ }^{10}$.

4. Gil Pujol, X.: «Notas sobre el estudio del poder como una nueva valoración de la historia política», Pedralbes, 3, 1983, pp. 61-88.

5. Una definición del poder como relación social vid. Carasa Soto, P.: «De la teoría de las élites a la historia de las élites», en Chacón Jiménez, F. y Hernández Franco, J. (eds.): Espacios sociales, universos familiares. La familia en la historiografía española. Murcia, 2007, pp. 93-95.

6. Gil Pujol, X.: «La historia política...», op. cit., pp. 198-202.

7. Guillamón Álvarez, F. J.: «El estudio del conflicto y del consenso desde una perspectiva integradora", en Guillamón Álvarez, F. J. y Ruíz Ibáñez, J. J.: Lo conflictivo y lo consensual en Castilla: sociedad y poder político, 1521-1715: homenaje a Francisco Tomás y Valiente. Murcia, 2001, pp. 13-24.

8. Remond, R.: El Antiguo Régimen y la Revolución. 1750-1815. Barcelona, 1983, pp. 160-164.

9. Sobre los límites de la categoría «opinión pública» aplicada a sociedades anteriores a las contemporáneas, vid. Alabrús Iglesies, R. M.a: «La trayectoria de la opinión política en la España moderna», Obradoiro de Historia Moderna, 20, 2011, pp. 337-338; Enciso Recio, L. M.: «Los mensajes de la opinión pública y la propaganda en la España Moderna», en VV. AA.: Propaganda y opinión pública en la Historia. Valladolid, 2007, pp. 49-90; Losa Serrano P. y López Campillo, R. M. ${ }^{a}$ : «La Guerra de Sucesión española y la opinión pública inglesa», en García GonzÁlez, F. (coord.): La Guerra de Sucesión en España y la Batalla de Almansa. Europa en la Encrucijada. Madrid, 2007, pp. 133-138.

10. EgIDo López, T.: Opinión pública y oposición al poder en la España del siglo XVIII (17131759). Valladolid, 2002, pp. 99-110. 
A pesar de las carencias de información o su suministro interesado y parcial con el fin de orientar reacciones en uno $u$ otro sentido, los diversos materiales generadores de opinión contribuían a formar y deformar en el imaginario popular, variedad de representaciones y discursos que circulaban entre una sociedad no tan indiferente a la toma de decisiones ${ }^{11}$. La publicística ${ }^{12}$, el género satírico ${ }^{13}$, publicaciones periódicas ${ }^{14}$, hasta las cartas y otros muchos escritos y memoriales ${ }^{15}$, servían como canales para la transmisión de gran parte de la tensión política del momento. Un lugar privilegiado debería ocupar la tertulia. En una sociedad que expresaba mayoritariamente sus opiniones través de discursos no escritos, la comunicación oral y la conversación (la palabra hablada), debían converger igualmente en la recepción y socialización del hecho político ${ }^{16}$.

Numerosas son las tertulias «eruditas» que se conocen en España a finales del siglo XvII coincidiendo con el inicio del movimiento de los «novatores» ${ }^{17}$; se trata, por lo general, de reuniones y foros elitistas celebrados en las residencias de algunos notables de la corte o las principales ciudades de la monarquía, donde además de política, se discute de literatura, jurisprudencia, ciencia, etc. La práctica de este tipo de tertulias continuará a lo largo del siglo siguiente, institucionalizándose alguna de ellas, lo que dará lugar a no pocas Reales Academias o Sociedades Económicas ${ }^{18}$, nuevos espacios de sociabilidad cultural pronto asimilados en la creciente maquinaria estatal de los borbones ${ }^{19}$.

11. Castillo Gómez, A. y Amelang, J. (coords.), Opinión pública y espacio urbano en la Edad Moderna. Madrid, 2010, en espec. pp. 337-513. Olivari, M.: Avisos, pasquines y rumores. Los comienzos de la opinión pública en la España del siglo XVII. Madrid, 2014, pp. 11-18.

12. Pérez Picazo, M. ${ }^{a}$ T.: La publicística española en la Guerra de Sucesión, vol. I-II. Madrid, 1966.

13. Gastón Pérez, J. (ed.): La rebelión de las palabras. Sátiras y oposición politica en Aragón (1590-1626). Zaragoza, 2003; García García, B. J.: «Sátira política a la privanza del duque de Lerma», en Guillamón Álvarez, F. J. y Ruíz Ibáñez, op. cit., pp. 261-298; Egido López, Sátiras políticas... op. cit.

14. Enciso Recio, L. M.: «Prensa y opinión pública», en VV. AA.: La época de los primeros Borbones. La cultura española entre el Barroco y la Ilustración. (1700-1759), vol. II, Historia de España-Menéndez Pidal, tomo XXIX. Madrid, 1985, pp. 197-258.

15. Bouza Álvarez, F. J.: Corre manuscrito: Una historia cultural del Siglo de Oro. Madrid, 2001, pp. 31-74 y 153-168.

16. Sobre la transmisión oral del discurso político, son de interés las páginas de STORRs, C.: La resistencia de la Monarquía Hispánica (1665-1700). Madrid, 2013, pp. 279-284.

17. Abellán, J. L.: Historia crítica del pensamiento español, vol. III. Madrid, 1981, pp. 355-370; Pérez Magallón, J.: Construyendo la modernidad: la cultura española en el tiempo de los novatores (1675-1725). Madrid, 2002, pp. 78-99.

18. Véase a modo de ejemplo el caso de la Real Academia Española, vid. Zamora, A.: Historia de la Real Academia Española. Madrid, 1999, pp. 23-33; o la propia Real Academia de la Historia, vid. Velasco Moreno, E.: La Real Academia de la Historia en el siglo XVIII: una institución de sociabilidad. Madrid, 2000, pp. 48-58.

19. Franco Rubio, G.: «El ejercicio del poder en la España del siglo XviII. Entre las prácticas culturales y las prácticas políticas», Mélanges de la Casa de Velázquez, 35,1, 2005, pp. 51-78. 
Junto a las anteriores, hemos de destacar en el amplio campo de la tertulia, también las de contenido netamente político. Sirva para su definición aquella otra genérica propuesta por Teófanes Egido, al presentarlas como reductos de la opinión, del comentario y la crítica ${ }^{20}$. La tertulia, lugar donde se comentan rumores, noticias y demás informaciones en un ambiente cercano que propicia la toma de partido, se convierte así en un medio de extraordinario valor para pulsar la forma de esa otra política, aquella que salta de los textos legales o escapa de las paredes de las instituciones y llega a un público mayor, sobre la que se habla o banaliza con cierto desprendimiento.

Surgidas en ocasiones como centros de oposición ${ }^{21}$, con un marcado carácter coyuntural y de vida generalmente corta o intermitente con apenas rastro documental tras sí, las dificultades para definir con precisión sus límites, miembros y actuaciones son indudables. Mayores son los apuros si lo que se pretende examinar es una tertulia alejada de los grandes espacios de decisión, no sujeta a reglas formales y más propia del ámbito socio-familiar, en la que se reúne un número reducido de personas del entorno más próximo (parientes, amigos, vecinos, etc.) para discutir o realizar comentarios acerca de algún acontecimiento o medida reciente. Un tipo de reunión que se asemejaría por su carácter ocasional y chismoso a la definición de conventículo recogida por Covarrubias ${ }^{22}$.

En nuestro caso, gracias a la excepcionalidad de las fuentes inquisitoriales, podemos analizar, a través de una de estas últimas tertulias informales, un episodio no menor de la lucha entre partidarios y detractores de la política regalista que se intentará a comienzos del reinado de Felipe V. Contextualizado en el proceso que terminará con la caída política y el inicio del exilio del fiscal general del consejo de Castilla, Melchor Macanaz (febrero de 1715), saldrá a la luz de las pesquisas de la Inquisición un grupo de partidarios que su hermano fray Antonio Macanaz, prior del convento dominico de la ciudad de Murcia, había logrado acaudillar. Allí forjarán un discurso y una interpretación de los hechos cuya dimensión rebasará pronto los límites conventuales, atrayendo la atención de numerosos interesados en la suerte seguida por Macanaz. Las declaraciones de los testigos llamados a la causa de don Melchor, junto al análisis de las cartas remitidas desde la Inquisición local a la Suprema durante la prisión de fray Antonio, nos permitirán rastrear y perfilar las actuaciones de proselitismo llevadas a cabo por el grupo de partidarios de los hermanos Macanaz.

20. Egido López, T.: Opinión pública..., op. cit., p. 38.

21. Caso paradigmático será la tertulia que reunirá a buena parte de los nobles castellanos desplazados por la camarilla francesa de Felipe $\mathrm{V}$ en los primeros años de su reinado, vid. Peña IzQUIERdo, A. R.: La crisis sucesoria de la Monarquía española. El cardenal Portocarrero y el primer gobierno de Felipe V, vol. I, Tesis Doctoral. Universidad Autónoma de Barcelona, 2005, pp. 288-290.

22. «Pequeña junta pero siempre se toma en mala parte, por aquellos que hacen daño a la República, o de los particulares», Tesoro de la lengua castellana o española (1611), p. 236. 
Uno de los medios que aprovecharán para la difusión y comunicación de tales imágenes, será la participación en una tertulia local de ámbito doméstico. Celebrada durante el tiempo en el que tendrá lugar la salida de la corte de Macanaz, su análisis nos permitirá conocer cómo contempló aquel grupo la serie de sucesos que terminarán con la carrera política del fiscal, las cábalas y conjeturas sobre su posible regreso, así como las consecuencias que para el propio fray Antonio se desatarán a raíz de las acusaciones realizadas por muchos de los testigos, circunstancias finalmente aprovechadas por el obispo Belluga, para ajustar la respuesta en forma de castigo contra el líder de la parcialidad.

Ambos espacios, convento y tertulia, servirán para poner de manifiesto el interés con el que parte de la élite político-religiosa del reino de Murcia seguirá y participará en los acontecimientos que envolverán el fracaso del ministro regalista.

\section{MACANAZ y EL OBISPO BELLUGA: LA LUCHA POR LAS REGALÍAS}

La situación política originada tras la ruptura de relaciones entre la corte de Madrid y la Santa Sede (marzo de 1709), terminará por extremar las actitudes y los discursos mantenidos en plena contienda sucesoria ${ }^{23}$. El reconocimiento de Clemente XI al archiduque Carlos como monarca en los territorios italianos ocupados, así como la posterior reacción de Felipe V, prohibiendo todo tipo de comunicación con Roma y expulsando de Madrid al Nuncio ${ }^{24}$, dibujan una etapa de radicalización política dominada por dos grandes posiciones encontradas. El ideal regalista, expresado en la necesidad de reforma del Estado bajo la premisa de la afirmación de los derechos del rey y la limitación de inmunidades y privilegios particulares ${ }^{25}$, frente a la oposición «romanista» o antirregalista, identificada con el poder del Papa, directo o indirecto, al que debía subordinarse el monarca como medio para la conservación de la religión, fin primero de la coron ${ }^{26}$.

23. Vicent López, M. I.: «La cultura política castellana durante la Guerra de Sucesión», en Fernández Albaladejo, P.: Los Borbones. Dinastía y memoria de nación en la España del siglo XVIII. Madrid, 2002, pp. 225-232.

24. Martín Marcos, D.: El Papado y la Guerra de Sucesión española. Madrid, 2011, pp. 97-160 y $193-200$.

25. Egido López, T.: «El regalismo y las relaciones Iglesia-Estado en el siglo XVIII», en Mestre SAnchís, A. (dir.): La Iglesia en la España de los siglos XVII y XVIII. Madrid, 1979, pp. 125-164 y 226-249; ABELLÁn, op. cit., pp. 677-687.

26. Mestre SAnchís, A.: «La Iglesia y el Estado. Los concordatos de 1737 y $1753 »$, en VV. AA.: La época de los primeros Borbones. La cultura española entre el Barroco y la Ilustración. (1700-1759), vol. I, Historia de España-Menéndez Pidal, tomo XXIX. Madrid, 1985, pp. 283-300; EgIDo LópeZ T.: «El discurso teologizante del antirregalismo (1709)», en SERrano MarTín, E. (ed.): Felipe V y su tiempo. Congreso Internacional, vol. I. Zaragoza, 2004, pp. 925-932. 
El conflictivo escenario de 1709 , tenderá a pacificarse en los años inmediatamente posteriores coincidiendo con la favorable evolución de la guerra para los intereses de Felipe V. La búsqueda de una solución a la crisis entre Madrid y Roma, impondrá a finales de 1711 una actitud de mayor moderación en una y otra corte. El inicio de las negociaciones de París, tuteladas por Luís XIV, será reflejo de la voluntad de ambas partes para llegar a un acuerdo que pusiera fin a tal desencuentro ${ }^{27}$. La definición y consecución de este propósito, volverá a convertirse, sin embargo, en nuevo motivo de enfrentamiento.

La negociación del acuerdo o ajuste con Roma coincidirá con uno de los momentos álgidos del denominado reformismo regalista en el reinado de Felipe V. El grupo liderado por la camarera mayor de la reina, Ana Marie de la Trémouille (Princesa de los Ursinos), secundada por el hacendista Jean Orry y el confesor del rey Pierre Robinet, desplegará un proceso global de reformas que abarcará a la mayor parte de los pilares fundamentales del sistema ${ }^{28}$. Vinculado con este programa, Melchor Macanaz ${ }^{29}$, fiscal general del consejo de Castilla, aparece como el brazo ejecutor de la mayoría de medidas en que se concretará ${ }^{30}$. Tanto la Nueva Planta de los consejos (con la especial organización que se dota al de Castilla) $)^{31}$, como el proyecto de reforma de las universidades ${ }^{32}$ o el impulso al estudio del derecho real ${ }^{33}$, caracterizarán la ejecutoria del fiscal Macanaz. Una trayectoria en la que destacará su crítica regalista a la arquitectura económica de

27. Martín Marcos, op. cit., pp. 212-222.

28. Bernardo Ares, J. M. de.: «Felipe V: La transformación de un sistema de gobierno», en Serrano Martín, op. cit., pp. 967-990.

29. Sobre Macanaz sigue siendo imprescindible la biografía de Martín Gaite, C.: Macanaz, otro paciente de la Inquisición. Barcelona, 1982 (primera edición, 1969); destaca la reciente obra de Cano Valero, J.: Rafael Melchor de Macanaz. Político y diplomático ilustrado. Albacete, 2008.

30. Coronas González, S. M.: Ilustración y Derecho. Los fiscales del Consejo de Castilla en el siglo XVIII. Madrid, 1992, pp. 45-49 y 111-119.

31. Dedieu, J.-P.: «La nueva planta en su contexto. Las reformas del aparato del Estado en el reinado de Felipe V», Manuscrits, 18, 2000, pp. 118-121; Escudero, J. A.: «La reconstrucción de la administración central en el siglo XVIII», en VV. AA.: La época de... op. cit., pp. 81-175; FAYARD, J.: «La tentative de réforme du Conseil de Castille sous le règne de Philippe V (1713-1715)», Mélanges de la Casa de Velázquez, t. II, 1966, pp. 259-282.

32. Állvarez de Morales, A.: La ilustración y la reforma de la Universidad en la España del siglo XVIII. Madrid, 1988, pp. 34-35; Peset, M. y Peset, J. L.: La universidad española (siglos XVIII y XIX): despotismo ilustrado y revolución liberal. Madrid, 1974, pp. 80-81.

33. Sobre la formación jurídica del personal que sirve en la administración real en el siglo XviII, son de interés los puntos de vista contrapuestos de: Dedieu, J. P.: «La muerte del letrado», en Aranda PÉREZ, J. F. (coord.): Letrados, juristas y burócratas en la España Moderna. Cuenca, 2005, pp. 479-511; y Carabias Torres, A. M. ${ }^{a}$ : «¿La muerte del letrado? Consideraciones sobre la tipología del oficial español en el siglo XVIII», en Dios DE Dios, S. y ToRIJANo, E. (coords.): Cultura política y práctica del derecho. Juristas de Salamanca, siglos XV-XX. Salamanca, 2012, pp. 143-238. 
la Iglesia, la autonomía de sus temporalidades y la excesiva jurisdicción de sus tribunales ${ }^{34}$.

En este proceso de cambio, dirigido a convertir al rey en la fuente única de legitimación del espacio político ${ }^{35}$, el papel de la Iglesia y las relaciones con Roma volverán a ocupar el centro de la polémica tras la presentación del «Pedimento Fiscal de los cincuenta y cinco puntos» ${ }^{36}$. Redactado por el propio Macanaz, el texto en cuestión no dejaba de ser un simple borrador, un esquema de trabajo encargado por Felipe $\mathrm{V}$ a su fiscal, que sirviera de base para la negociación que en ese momento se estaba desarrollando con Roma. Entroncado en la tradición hispana del regalismo ${ }^{37}$, en él se recogerá la lista de agravios, excesos y abusos cometidos por la Dataría, acusándose de injustificable la jurisdicción del tribunal de la Nunciatura así como los perjuicios que para la fiscalidad del Estado resultaban las exenciones eclesiásticas e inmunidades locales. Finalmente, se reconocían al monarca ciertas facultades en asuntos de índole religioso, en concreto, en aquellas materias que tuvieran relación con el gobierno de lo temporal, a cuya jurisdicción real debía sujetarse la Iglesia ${ }^{38}$.

Para Macanaz y el resto del equipo regalista, ningún poder de naturaleza temporal podía escapar o sobrevivir ya de forma autónoma respecto al monarca. La Iglesia española, un eslabón más en la cadena de reformas, debía obediencia al rey, cumplir con sus leyes y solo en lo espiritual y cuestiones estrictamente de fe, seguir a Roma ${ }^{39}$. El avance del programa reformista conllevaba la inclinación de la balanza a favor del monarca. De la tradicional e idealizada armonía de poderes entre el rey y el reino, se pretendía una situación de predominio de la autoridad real, capaz de mediatizar e imponerse sobre cualquier cuerpo intermedio. Tal alteración del orden político, será percibida y denunciada por quienes, como el obispo Belluga, se opondrán con decisión a la actuación de los ministros reformistas de Felipe V.

34. Egido López, T.: «Las reformas fracasadas. El significado de Macanaz», en Villanueva Pérez J., Escandell Bonet, B. y Alcalá, A. (dirs.): Historia de la Inquisición en España y América, vol. I. Madrid, 1984, pp. 1234-1247.

35. El papel del rey como centro del sistema político y de gobierno de la monarquía española del siglo XVIII, vid. DeDIEU, J. P.: «El aparato de gobierno de la monarquía española en el siglo XVIII», en Pérez Sarrión, G. (coord.): Más Estado y más mercado: absolutismo y economía en la España del siglo XVIII. Madrid, 2011, pp. 53-74.

36. Editado por Maldonado Macanaz, J.: Melchor de Macanaz. Testamento político. Pedimento fiscal (edición y notas por Francisco Maldonado de Guevara). Madrid, 1972, pp. 91-123.

37. Reconocido por el propio Macanaz en carta al clérigo fray Alonso Rosique en diciembre de 1714, vid. Martín GaIte, op. cit., pp. 264-265.

38. EgIdo López, T.: «Las reformas fracasadas...», op. cit., pp. 1235-1237.

39. Mestre Sanchís, A.: «Nueva dinastía e Iglesia nacional» en Fernández Albaladejo, P.: Los Borbones..., op. cit., pp. 549-567; mismo autor, «La actitud religiosa de los católicos ilustrados», en Guimeré, A. (ed.): El reformismo borbónico. Una visión interdisciplinar. Madrid, 1996, pp. 147-163. 
Don Luis Belluga y Moncada, exponente más distinguido de la corriente antirregalista de la Iglesia española a comienzos del setecientos ${ }^{40}$, había criticado ya en su famoso «Memorial de $1709{ }^{41}$ la orientación regalista de la política de Felipe V, lo que a su juicio había contribuido a la dolorosa quiebra de relaciones con la Santa Sede. Cinco años más tarde, el obispo de Cartagena se dirigirá por carta al rey francés Luís XIV ${ }^{42}$, con el fin de denunciar el estado del gobierno «en lo político y eclesiástico, el desconsuelo y temores en que nos tiene puestos (...) y el despropósito con que se tratan las cosas sagradas y eclesiásticas» ${ }^{43}$. La carta de Belluga se constituía en una auténtica enmienda a la totalidad de la obra política personalizada en Macanaz y el confesor real Robinet.

El obispo repasará en su extensa comunicación, los perjuicios ocasionados por el gobierno regalista en lo tocante «a la justicia y lo temporal y político [como] a la religión, lo espiritual y eclesiástico: que son los dos polos en que se firman los reinos». No pasará por alto la nueva organización que, en noviembre de 1713, Orry y Macanaz habían dispuesto para los principales consejos de la monarquía, refiriéndose a ella como «perjudicialísima al rey y perjudicialísima a sus vasallos, perjudicialísima a la conciencia de los mismos jueces (...) y odiadísima a la nación», afirmando que con ella «pierde el reino en lo espiritual y temporal y pierde en la religión ${ }^{44}$ ».

Tampoco ahorrará tinta en criticar el «Pedimento». Después de lamentar como «todo lo eclesiástico y cuanto mira a lo espiritual hoy se gobierna por el fiscal general», entrará de lleno a desgranar -casi párrafo a párrafo- su contenido. El juicio del obispo no podrá ser más negativo en relación a un texto que según él, pretendía «desquiciar todas las prácticas de este reino y todo el derecho canónico» ${ }^{45}$. Para ello, daba noticia a Luis XIV de las numerosas afrentas recogidas en el «Pedimento», en el que su autor:

40. Martínez Ripoll, A.: «Regalismo borbónico, reformismo eclesiástico y relaciones con Roma: el cardenal Belluga», en Contreras, J., Alvar, A. y Ruiz, J. I.: Politica y cultura en la época moderna: Cambios dinásticos, milenarismos, mesianismos y utopías. Madrid, 2004, pp. 29-50; VILAR, J. B.: El cardenal Luís Belluga, Granada, 2005, pp. 250-258; Irigoyen López, A.: Un Obispo, una Diócesis, un clero: Luis Belluga, prelado de Cartagena. Murcia, 2005, pp. 11-18.

41. Martín Martínez, I.: «Fundamentos doctrinales e históricos de la posición antirregalista del cardenal Belluga», en Cremades Griñán, C. M.a: Estudios sobre el Cardenal Belluga. Murcia, 1985, pp. 59-83; ÉcIJA Rioja, M.: Tercer centenario del Memorial antirregalista del cardenal Belluga a Felipe V: un conflicto jurídico entre Iglesia y Estado en 1709. Murcia, 2010, pp. 45-130.

42. Archivo del Ministerio de Asuntos Exteriores de Francia. Correspondencia Política. España [en adelante, MAECPE], Mmss. 236, fols. 183r- 198v. Utilizada parcialmente por MARTín GAITE, op. cit., pp. 280-284.

43. MAECPE, Mmss. 236, fol. 187r.

44. Idem, fol. $188 \mathrm{v}$.

45. Idem, fol. $191 \mathrm{v}$. 
injuriaba a los prelados y religiones y estado eclesiástico, denunciando la inmunidad y jurisdicción eclesiástica; ofendía la autoridad y potestad pontificia y echaba por tierra la autoridad de los Concilios generales, celebrados desde el siglo doce, Decretales y Cánones Sagrados (...), todas ellas son proposiciones, unas temerarias, otras injuriosas y denigratorias de las religiones y de todo el estado eclesiástico, otras heréticas de la inmunidad y jurisdicción eclesiástica y de la autoridad y potestad Pontificia ${ }^{46}$.

Belluga no disimulará a Luis XIV la solución a los males de la monarquía, requiriendo la ayuda del monarca francés para que interviniera en un problema individualizado en Macanaz y Robinet. La salida de ambos de la corte bastaría para recobrar el estado anterior del gobierno y la religión. Con este objetivo, rogaba a Luis XIV que «disponga que salga de aquí con algún pretexto, el padre Robinet y haga de la misma forma don Melchor Macanaz, fiscal general de la corte, en lo que está todo el remedio» ${ }^{47}$.

La opinión del obispo será bastante representativa del rechazo que para ciertos grupos y personas generaba la acción del gobierno regalista. Junto a un sector de la Iglesia, también mostrará su oposición parte del establishment político contrario a la ola de reformas impulsadas por el fiscal, caso del consejero de Castilla Luís del Curiel. Cabeza visible de una liga de consejeros contrarios a Macanaz ${ }^{48}$, Curiel llegará a rebatir y criticar sin disimulo algunas de las conclusiones más polémicas del «Pedimento» ${ }^{49}$.

La oposición a las reformas, cada vez más visible y en aumento a lo largo de 1714, encontrará un apoyo casi definitivo en el tribunal de la Inquisición. Filtrado por Curiel el texto del «Pedimento» al inquisidor general Del Giudice, su precipitada condena en el mes de julio sumará una vuelta de tuerca más a la ya de por sí tensa situación ${ }^{50}$; solo la privanza de Ursinos sobre el rey viudo mantendría todavía a salvo al impopular tándem formado por Macanaz y Orry. La defenestración final de Ursinos en diciembre de 1714 y el relevo en la camarilla de los reyes, tras la llegada de la nueva esposa de Felipe V -la parmesana Isabel de Farnesio-,

46. Idem, fols. $192 \mathrm{r}-194 \mathrm{r}$.

47. Idem, fol. $197 \mathrm{r}$.

48. FAYARD, J.: «La tentative de...», art. cit., pp. 274-279.

49. Voto de don Luis Curiel sobre el requerimiento hecho al consejo por el señor fiscal general, sobre puntos de jurisdicción e inmunidad eclesiástica y sobre el remedio de algunos abusos y otras cosas, Real Academia de Historia [en adelante, RAH], Mss. 9/1510, fols. 61r-129v. Hernández Franco, J. y Precioso Izquierdo, F.: «Discursos enfrentados en los albores de la Monarquía borbónica. Reacciones al Pedimento Fiscal de Macanaz», Mediterranea-ricerche storiche, 30, 2014, pp. 77-82.

50. Macanaz contraatacará proponiendo la reforma del santo Tribunal; demasiado tarde, su propuesta se constituirá en referente de posteriores iniciativas de reforma de la Inquisición, vid. García-Hevia, J. M.a: «Macanaz y su propuesta de reforma del Santo Oficio de 1714», Revista de Inquisición, 5, 1996, pp. 218-327. 
terminará por truncar el recorrido del equipo regalista. La victoria de la oposición forzará la pérdida del empleo de Macanaz, quien en febrero de 1715 marchará a Francia con permiso del rey con la excusa de ir a tomar las aguas a Bagnères. El exilio del político hellinero había comenzado.

De forma paralela y como corolario del enfrentamiento político, se iniciará el proceso inquisitorial contra don Melchor. Una operación instada por sus enemigos con el beneplácito de la Iglesia e instrumentalizada por una Inquisición, que como denunciará el propio Macanaz, hará «instrumento de la religión para venganza de sus pasiones» ${ }^{51}$.

\section{Murcia, ReINo DE LOS MACANAZ Y DióCESIS DE BELluga}

La lucha por el poder entre gobernantes será seguida con interés más allá de la corte. Uno de los territorios donde mayor atención despertará la caída política de don Melchor será el reino de Murcia. Cuna de los Macanaz (naturales de Hellín, al norte del reino) y sede episcopal de Belluga, en él confluirán los dos polos del conflicto, circunstancia que justificará la curiosidad de parte de la población, ávida de noticias sobre la suerte de uno de sus paisanos, derrotado -entre otros- por la cabeza de su Iglesia.

El obispo Belluga se había convertido desde su llegada a la diócesis murciana (abril de 1705), en el auténtico líder -no solo espiritual- del reino. Su apuesta por los derechos a la corona de Felipe de Anjou, así como su destacado papel en la defensa del territorio -movilizando milicias locales y actuando de fuerza de choque ante el avance del ejército austracista ${ }^{52}$ - permitirán al reino de Murcia mantener, en líneas generales, una bien trazada y recompensada fidelidad a la causa borbónica ${ }^{53}$. Concluida la guerra, el prelado conservará y acrecentará su influencia, constituyéndose en una de las voces políticas más autorizadas tanto dentro como fuera del reino.

Las discrepancias ideológicas - puestas ya de manifiesto- con Melchor Macanaz, pronto descubrirán una insalvable distancia también en lo personal. Las diferencias en cuanto a la política regalista y su repercusión en el vidrioso complejo de inmunidades y exenciones eclesiásticas, dará lugar a uno de los primeros y más sonados roces entre el obispo y el ministro murciano. Belluga, que había acudido a la corte a finales de 1713 alertado por el nuevo impuesto con el que se pretendía

51. Carta de Melchor Macanaz a José Grimaldo. Pau, 8 de junio de 1717, Archivo General de Simancas [en adelante, AGS], Estado, leg. 4690, s/f.

52. Muñoz Rodríguez, J. D.: Felipe $V$ y cien mil murcianos más. Movilización social y cambio político en la Corona de Castilla durante la Guerra de Sucesión (1680-1725), Tesis Doctoral. Universidad de Murcia, 2010, pp. 84-86 y 203-235.

53. VILAR, op. cit., pp. 39-84. 
gravar al clero por la venta de la sal, responsabilizará directamente a Macanaz de las dificultades que harían fracasar su entrevista con Felipe $\mathrm{V}^{54}$. De esto se quejará en la carta anterior a Luis XIV, reprochando a la camarilla regalista del rey:

no permitidle que vasallo alguno le hable a solas y le diga lo que pasa, y si alguno lo hace, o se teme lo pueda hacer, y que si conoce como SM lo mira bien y lo atiende, y tiene de él confianza, inmediatamente se le destierra o se le aparta de su lado, calificándolos y poniéndolos con SM de mala fe, de desafectos, de lo que tenemos bastante ejemplares ${ }^{55}$.

La cosmovisión antagónica de uno y otro se dejará notar en las cartas entrecruzadas remitidas entre ambos durante los meses de influencia política de Macanaz. Comentadas con minuciosidad por Martín Gaite, la correspondencia sobre limosnas y modas rebosará un profundo distanciamiento, aderezado con ciertas notas de vanidad por parte del fiscal hacia Belluga ${ }^{56}$. Sin embargo, a pesar de la enorme brecha que les separa, también habrá momento para la colaboración y el encuentro. Prueba de ello será la aparente buena acogida con la que el prelado contestará a algunos de los pedimentos propuestos por don Melchor, como el relativo a la conveniencia de crear una red de colegios-seminarios donde educar adecuadamente a los futuros sacerdote ${ }^{57}$, o la necesidad de construir casas para niños y niñas huérfanas ${ }^{58}$.

La relación de Belluga con don Melchor no excluirá al resto de miembros de la familia Macanaz. Escenario casi inadvertido, hoy sabemos que Belluga conocía y estaba al tanto de los hermanos del fiscal. Tal será el caso de don Ginés Macanaz, único de los cuatro hermanos que permanecerá durante toda su vida en la villa de Hellín ${ }^{59}$. Presbítero de la iglesia parroquial, juez apostólico y comisario subdelegado de la Santa Cruzada en el partido hellinero, en diciembre de 1714 recibía directamente de Belluga el nombramiento de fiel y colector de las rentas y frutos decimales correspondientes a las tierras de la localidad ${ }^{60}$.

54. Mestre Sanchís, A.: «La Iglesia...», op. cit., pp. 296-297.

55. MAECPE, Mmss. 236, fol. 187r.

56. Martín Gaite, op. cit., pp. 241-245.

57. Barrio Gozalo, M.: «El clero bajo sospecha a principios del siglo XviII. El informe de Macanaz y la respuesta de los obispos», Investigaciones históricas, 22, 2002, pp. 55-56.

58. Castro Monsalve, C. de: «La Nueva Planta del Consejo de Castilla y los pedimentos de Macanaz», Cuadernos de Historia Moderna, 37, 2012, pp. 35-37.

59. Primogénito de los hermanos Macanaz, había nacido en Hellín el 22 de diciembre de 1664, Archivo Histórico de la Diócesis de Albacete [en adelante, AHDAb], Bautismos, 1653-1671, fol. 199v. Sobre los orígenes familiares de los Macanaz vid. Precioso Izquierdo, F.: «Encubrimiento familiar, proyección política: Los Macanaz (1630-1700)», Chronica Nova, 38, 2012, pp. 203-220.

60. Archivo Histórico Provincial de Albacete [en adelante, AHPAb], Protocolo n. ${ }^{\circ} 1969$, fols. 94r-97v (20-12-1714). 
Unos meses antes había tenido lugar la recepción de la primera tonsura del bachiller en cánones Juan Narciso Macanaz, hijo de otro de los hermanos de don Melchor, don Luis Antonio Macanaz ${ }^{61}$. El 19 de abril de 1713, el obispo Belluga había celebrado la ceremonia de ordenación del joven Juan Narciso, otorgándole semanas después las cartas dimisorias en previsión de la futura merced con la que Felipe V premiará al sobrino de su fiscal (una ración en la Iglesia-Catedral de Málaga, de la que tomará posesión en diciembre de 1715) ${ }^{62}$.

Más complicada será la relación de Belluga con el padre fray Antonio Macanaz ${ }^{63}$. Fraile de la Orden de los Predicadores en el convento de Santo Domingo de la ciudad de Murcia ${ }^{64}$, había llegado a ser prior coincidiendo con el periodo en el que su hermano se encontraba al mando del consejo de Castilla. Fray Antonio sabrá beneficiarse del influyente empleo de don Melchor, hasta el punto que será nombrado consejero de la Inquisición en la proyectada reforma propuesta en $1714^{65}$. Consciente del enorme predicamento de fray Antonio tras su designación como consejero del Santo Tribunal, el corregidor de Murcia no dudará en convocar una sesión extraordinaria del concejo, para dar a conocer la noticia y organizar los festejos con los que la ciudad honraría su nombramiento:

61. Tras participar en su conquista, don Luís Antonio será nombrado Sargento mayor de Denia en diciembre de 1709 en AGS, Estado, Libro 486, s/f. Acreedor de una larga carrera militar, había servido en Nápoles a comienzos de siglo bajo las órdenes del entonces virrey de la plaza, don Juan Manuel Fernández Pachecho, VIII marqués de Villena, patrón de su hermano don Melchor, vid. Martín Gaite, op. cit., pp. 175-182; Precioso Izquierdo, F.: «El beneficio de la fidelidad: Melchor Macanaz y la casa de Villena (1694-1706)», en Martínez Millán, J., Camarero, C. y Luzzi, M. (coords.): La corte de los Borbones: crisis del modelo cortesano. Madrid, 2013, pp. 1163-1181.

62. Vida de D. Juan Narciso Macanaz, Biblioteca de la Abadía de Montserrat [en adelante, BAM], Mmss. 902-VII, s/f.

63. El más joven de los hermanos Macanaz había nacido en Hellín el 25 de marzo de 1675, AHDAb Bautismos, 1671-1688, fol. 101r. En el curso 1692-1693 iniciaba en la Universidad de Salamanca el Bachiller de Cánones, Archivo Universidad de Salamanca, [en adelante AUSA], Libro de Matrícula 400, fol. 34v.

64. El mismo Macanaz se referirá a la viva participación del convento dominico en pro de la causa de Felipe V durante la Guerra de Sucesión. En Murcia, según don Melchor, los frailes llegarían a movilizarse en defensa de la ciudad durante el sitio al que fue sometido por el ejército austracista a finales de agosto de 1706: «la nobleza y muchos particulares se animaron desde luego a la defensa, las religiones y con especialidad la de Santo Domingo hizo salir sus misioneros y otros predicadores a exortar al pueblo a defenderse». Memorias para la Historia, Biblioteca del Palacio Real, Mmss. 2084, fol. 101v.

65. En el decreto de su nombramiento se especificaban las razones: «Por muerte del maestro fr. Froilán Díaz, de la Orden de Santo Domingo, se halla vaca la plaza que ocupaba para la Religión en ese consejo de Inquisición, y teniendo presentes los méritos y especiales circunstancias que concurren en la persona de fr. Antonio Macanaz, prior de mi Real Casa de Santo Domingo de Murcia, he venido en conferirle dicha plaza», A. G. S. Gracia y Justicia, leg. 835, s/f. Los acontecimientos que terminaron con el cese y la salida de la corte de don Melchor impedirán a fray Antonio tomar posesión de la misma, vid. GARCIA-HeviA, J. M.a: «Macanaz y su...», art. cit., pp. 265 et passim. 
siendo el gusto con que esta ciudad debe celebrar tan plausible promoción correspondiente a los méritos del M. R. Padre presentado y a la particular estimación que esta ciudad hace de su persona así por la que se ha sabido adquirir como por nativo de este reino; prior de este convento y hermano del señor don Melchor Rafael Macanaz, del consejo de S. M., su fiscal general, a quien esta ciudad y toda su provincia deben tan especiales atenciones. Es indispensable a su obligación corresponder agradecida en sus públicas demostraciones que acrediten las veras con que desea manifestar su alborozo, a cuyo fin, acordó se pongan luminarias ${ }^{66}$.

Semanas más tarde, dos regidores murcianos comisionados en Madrid informarán al concejo de los rumores que circulaban en la corte sobre «dicho reverendo padre [fray Antonio] va consultado en primer lugar en el Obispado de Osma» ${ }^{67}$. Los regidores confirmaban así la carrera en ascenso del hermano de Macanaz, quien tras recibir el nombramiento de consejero de la Inquisición se preparaba ahora para acceder al obispado de Osma. Sin embargo, el inicio de la fulgurante trayectoria de fray Antonio vendrá a coincidir con el ocaso político de don Melchor, lo que al parecer le habría obligado por cautela a rechazar el obispado de la diócesis soriana poco antes de la defenestración de Macanaz.

\section{CONVENTO Y TERTUlia: Focos DE OPOSICIÓN Y CANALES DE TRANSMisión POLÍTICA EN LA MURCIA BORBÓNICA}

La relación entre el prior y el obispo Belluga no será en absoluto cordial. Las diferencias con las reformas impulsadas por don Melchor serán el principal motivo de discrepancia. El grado de divergencia se había manifestado ya durante un encuentro mantenido entre ambos durante la Navidad de 1714. La dureza con la que fray Antonio había defendido el contenido del «Pedimente Fiscal» llegó a sorprender al propio Belluga. Tras la discusión, el obispo llegará a responsabilizar a fray Antonio de ser quien «acaloraba» a su hermano en las materias más polémicas del documento ${ }^{68}$.

Desde entonces, y en especial tras la salida de la corte de don Melchor, el obispo no cejará en la denuncia del dominico, a quien tratará de anular con la complicidad de la Inquisición y parte de la comunidad de frailes opuesta al prior.

66. Archivo Municipal de Murcia [en adelante AMM] Actas Capitulares, 30 de diciembre de 1714, fols. $267 \mathrm{v}-268 \mathrm{r}$.

67. AMM, Actas Capitulares, 29 de enero de 1715, fols. 19v-20r.

68. Martín GaITe, op. cit., p. 340. 


\subsection{La parcialidad murciana de los Macanaz}

Iniciado ya el proceso contra el ex fiscal, Belluga dará cuenta al inquisidor Del Giudice de la «larga parcialidad que tienen en Murcia don Melchor y el padre» ${ }^{69}$. Se refería el obispo al grupo de partidarios de Macanaz que su hermano fray Antonio había logrado reunir en torno a él en el convento local de Santo Domingo. Un grupo heterogéneo, compuesto por clérigos y seglares, en el que se entrecruzaban lazos de amistad, vecindad y paisanaje. El listado de los «apasionados», «afectos» o «dependientes» de los Macanaz, lo darán a conocer varios testigos llamados a declarar en la sumaria de fray Antonio. Uno de ellos, fray Ignacio de la Portilla, lector de Teología en el convento dominico, incluirá a los frailes Martín y Juan Truyol, a los hellineros fray Gonzalo de Soria (sustituto de fray Antonio como prior) y fray Juan Izquierdo (maestro de estudiantes), así como a fray Felipe Dardalla (maestro de novicios) y los hermanos fray Juan y fray Fulgencio Velando. Entre los seglares que «vienen a la celda de dicho fray Martín a saber las noticas que ay de dicho don Melchor», identificará a los regidores Antonio Talón y Francisco Zetina, al conde de Montealegre y a un tal Bartolomé Velando ${ }^{70}$. Otro de los testigos, fray Fernando Rejón de Silva, completará la lista de seglares añadiendo los nombres del médico Juan Jiménez y el abogado Juan Antonio Navarro, del que dice «fue pasante de dicho don Melchor en Madrid ${ }^{71}$ ».

Nos encontramos, por tanto, ante un colectivo variado, compuesto principalmente de frailes a los que se unirían de forma ocasional algunos regidores y profesionales cercanos a los Macanaz. Difícil de detectar en estos casos, parece sin embargo que el grupo guardaba una cierta jerarquía interna y que el nivel de implicación se diferenciaba de unos a otros. Así se desprende de la declaración anterior de Rejón de Silva, quien señalará a fray Martín Truyol como la persona de confianza y el enlace de fray Antonio con el resto de sus seguidores. Según el declarante, sería Truyol el primero a quien fray Antonio comunicaba las noticias relativas a su hermano, siendo éste «quien las participa a los demás de sus afectos assi religiosos como seglares» ${ }^{72}$.

Las informaciones recibidas por Truyol procederán a su vez de la correspondencia que seguirán manteniendo entre sí los hermanos Macanaz. Una comunicación cada vez más difícil, articulada en torno a un buen número de argucias con las que tratarán de burlar el cerco de la Inquisición. Ejemplo de las tretas utilizadas, será

69. Idem, p. 341.

70. Declaración de fray Ignacio de la Portilla. 13 de septiembre de 1715, Archivo Histórico Nacional [en adelante, AHN], Inquisición, leg. 3697-2, fols. 43v-44r.

71. Declaración de fray Fernando Rejón de Silva. 11 de septiembre de 1715, AHN, Inquisición, leg. 3697-2, fols. 41r-43r.

72. Idem, fol. $42 \mathrm{r}$. 
el sistema de comunicación seguido entre fray Antonio y su hermano durante el tiempo que pasará el primero en el convento de Santo Domingo de la ciudad de Chinchilla. La estancia en aquel de fray Antonio tendrá lugar en los meses de verano de 1715, al poco de iniciarse la causa contra don Melchor; la sensación de inseguridad experimentada por el dominico en Murcia parece ser la razón principal que moverá a fray Antonio a «refugiarse» en Chinchilla, lejos del obispo Belluga.

En los apenas tres meses que permanecerá en esta ciudad, coincidirá con el ciezano don Matías Marín Blázquez ${ }^{73}$, corregidor de la plaza. La amistad de los Macanaz con Marín Blázquez será puesta de manifiesto por la mayoría de los testigos, quienes señalarán al corregidor como una de las piezas clave que hará posible la comunicación entre los dos hermanos. Los continuos rumores que circulaban en el convento sobre la llegada a Pau (Francia) de Macanaz y sus entrevistas con destacadas autoridades -como el nuevo confesor del rey, Guillermo Daubenton ${ }^{74}$ remitían, según fray Ignacio de la Portilla, a la misma fuente de información. La correspondencia se realizaba utilizando «apellidos supuestos», siendo facilitada por uno de los criados que Macanaz había dejado en Madrid.

Parece que con objeto de levantar el ánimo de su hermano, manteniendo viva la esperanza sobre su posible regreso, don Melchor no dejaba de enviar numerosas cartas y escritos desde su retiro en Pau. Textos en los que parecía atisbarse una pronta y satisfactoria solución, que el propio fray Antonio se encargaba posteriormente de difundir entre el resto de partidarios. Para que esta correspondencia llegara hasta el prior, se utilizaba a Luis Sánchez Ulloa (mano derecha de Macanaz durante buena parte de su trayectoria política ${ }^{75}$ ) quien enviaba los pliegos a nombre del corregidor de Chinchilla «por cuya mano tuvo muchas cartas el padre presentado» ${ }^{76}$.

A parte de fray Martín Truyol, otro de los frailes más cercanos a fray Antonio será fray Juan Velando, a quienes los testigos se referirán como el «amanuense» que redactaba las cartas del prior. En cuanto a los seglares seguidores de los Macanaz, no parece que el nivel de implicación fuera más allá del mero interés por conocer

73. Sobre la trayectoria de Matías Marín Bláquez, vid. Muñoz Rodríguez, J. D.: Felipe Vy..., op. cit., p. 265.

74. Según Macanaz, parece que inicialmente el padre Guillermo Daubenton se había mostrado favorable a la revisión de su proceso, actitud que tras llegar a Madrid había mudado notoriamente. Este cambio de parecer lo achacará Macanaz a las intrigas del inquisidor Del Giudice, quien habría atraído al nuevo confesor «facilitando que desde Roma le ofreciesen el capelo (...), decidiendo anteponer a la justicia su conveniencia». Referencias localizadas en la obra atribuida a Macanaz, Agravios que me hicieron y procedimientos de mis enemigos para perseguirme y arruinarme (Lieja, 1748). Hemos utilizado una copia conservada en AHN, Sección Nobleza, Fernán Núñez, C. 2043, 6, fols. 150r-164v.

75. Martín Gaite, op. cit., pp. 143-146 y 266-280.

76. Declaración de fray Ignacio de la Portilla (...), fols. 46r-46v. 
las novedades sobre las circunstancias del ex fiscal, limitándose a acudir al convento los días de correo a saber las noticias de don Melchor.

En general, la información que proporcionan los testigos alude muy escasamente a argumentos teológicos o de política religiosa que pudieran ayudarnos a interpretar a este grupo como una corriente afín a las reformas de cuño regalista impulsadas en este periodo. Acaso, el único que parece identificarse con alguna de las iniciativas planteadas por el propio don Melchor será su hermano fray Antonio. Así se desprende de la declaración de fray Diego López de Castilla (de la orden de nuestra Señora de la Merced), quien revelará una conversación mantenida en diciembre de 1714, en la que el entones prior del convento dominico «tocó la especie de dicho papel de su hermano». Fray Diego pondrá en boca de fray Antonio:

que el papel [Pedimiento de los 55 párrafos] no tenia la censura que se le había dado porque aunque en el cuerpo se veían algunas proposiciones disonantes, evacuaba toda la censura con el primer y ultimo parrafo, respecto de que en el primero confesaba las dos jurisdicciones Pontificia y real y en el último concluía pidiendo que para remedio de todos los males se consultasen medios a SM, y al Papa en lo que el rey no alcanzase, y que debiéndose entender todo debajo esta clausula sacando Bula del Papa (...), y que ojalá se pusiera en planta pues cesarian las exorbitadas contribuciones que de España iban a Roma y se lograría el mismo alivio que en Francia y otras monarquías ${ }^{77}$.

El testimonio de fray Diego recoge también la versión de fray Antonio sobre su tenso encuentro con Belluga. Según confesión del dominico, este había hablado a «su excelencia en él de dicho Papel [«Pedimento»] como queriéndolo persuadir, pero que le había respondido muy bien, dando a entender que el genio de dicho señor obispo era muy diferente al suyo y que nunca se convendrían ${ }^{78}$.

Los lazos de amistad y cercanía fraguados en el convento a partir del trato cotidiano entre frailes y algunos seglares se constituyen en los elementos decisivos en la formación de la parcialidad murciana de los Macanaz. Afecto y proximidad que no tendrán porqué excluir aquellos «otros intereses» denunciados por el propio Belluga, relativos a los beneficios en forma de «obispados, prebendas, plazas, y corregimientos» con que fray Antonio tenía esperanzados a sus seguidores ${ }^{79}$.

Todo apunta, en definitiva, al efectivo liderazgo del hermano de don Melchor como aglutinante y referente del grupo. Un líder que sabrá ganar adeptos a su causa a través de una concienzuda labor desplegada por medio de la conversación y persuasión. El modo de actuación de fray Antonio será reflejado por la

77. Declaración de fray Diego López de Castilla. 29 de agosto de 1715 en AHN Inquisición, leg. 3697-2, fol. 33v.

78. Idem, fol. $34 \mathrm{r}$.

79. Martín Gaite, op. cit., pp. 340. 
mayoría de testigos, quienes si bien terminan rechazando cualquier coincidencia con sus proposiciones, no deja de ser válido para conocer las formas con las que el prior tratará de acercarse a otros frailes. Así, la conversación denunciada por fray Diego López de Castilla a los inquisidores, dibuja un fray Antonio interesado en desmontar la condena de la Inquisición al «Pedimento Fiscal», diciendo «que se había hecho en ello injusticia (...) que con el Edicto que condena dicho papel, se había desbaratado la Composición con la corte de Roma que estaba muy adelantada ${ }^{80}$. Mayores detalles recoge el testimonio del dominico fray Domingo López, quien presenta a fray Antonio haciendo «campaña» en el convento a favor de su hermano, utilizando las cartas que don Melchor le enviaba desde Francia. Especial revuelo causará la remitida por el fiscal al obispo Belluga a cuenta del nuevo impuesto de la sal ${ }^{81}$. Sobre la misma, declarará fray Domingo haber visto:

copia de una carta al obispo de esta ciudad, la qual leyó al declarante, pareciéndole muy injuriosa a dicho señor obispo y a los ministros de Roma (...) a lo cual contesto dicho padre presentado Macanaz, diciendo que tenía testimonios y evidencias el dicho su hermano de agravios recibidos de dicho señor Obispo que merecían aquella respuesta $^{82}$.

Otro de los testigos, esta vez uno de los parciales de los Macanaz, el hellinero fray Gonzalo de Soria, describirá en su declaración la manera con la que fray Antonio tratará de normalizar y quitar gravedad al impacto causado en el convento por la condena del «Pedimento». En su respuesta a la pregunta de los inquisidores acerca de si había leído el papel condenado, afirmaba que:

pocos correos después de haber venido a Murcia la noticia del edicto publicado en Madrid que condenaba el papel de dicho don Melchor de Macanaz, entró el declarante en la celda del dicho padre presentado fray Antonio Macanaz, su hermano, y le dijo que qué ruido era este del papel de su hermano, a lo qual el dicho padre presentado sacó un papel que le parece tenía en el pecho y le leyó una o dos o tres proposiciones de él, de cuyo contenido no se acuerda ${ }^{83}$.

Avanzado el interrogatorio, fray Gonzalo dejaba caer la posibilidad de que fray Antonio le hubiera leído solamente ciertos párrafos cuyo contenido fueran los de menor polémica, con el ánimo -aseguraba- «de satisfacerle de que su hermano

80. Declaración de fray Diego López de Castilla (...), fol. 33r.

81. En el voluminoso proceso inquisitorial contra don Melchor se conserva una copia de la carta a la que se referirá Martín GaITE, op. cit., pp. 242-243.

82. Declaración de fray Domingo López. 11 de septiembre de 1715, en AHN, Inquisición, leg. 3697-2, fols. 37v-38r.

83. Declaración de fray Gonzalo de Soria. 20 de septiembre de 1715, en AHN, Inquisición, leg. 3697-2, fols. 48v-49r. 
FRAY ANTONIO MACANAZ Y EL OBISPO BELLUGA (1714-1720)

no había escrito las proposiciones que con tanto horror se referían», concluyendo que «las que leyó al declarante, o por ser las proemiales o por ser diminutas, no contenían cosa especial ni la censura que se le dio a todo el papel ${ }^{84}$. La ocultación de determinadas partes del «Pedimento» no sería de extrañar a tenor de la reacción de algunos frailes al conocer la noticia de la condena del texto. Uno de ellos, el ya traído fray Domingo López, extrañado al ver colgado el edicto condenatorio en la puerta de la catedral murciana, llegaría incluso a preguntar a fray Antonio si «le habían impuesto las proposiciones condenadas o si se las habían adulterado, a lo qual no contexto dicho fray Antonio» ${ }^{85}$.

\subsection{La tertulia de la casa Lucas-Guill}

Precisamente fray Gonzalo de Soria será uno de los seguidores de los Macanaz que participará en la tertulia celebrada en la casa de doña Luisa Guill Verástegui, viuda de don Juan Lucas Marín. Se trataba de una de las familias de la oligarquía local más señaladas por su apoyo a la causa del Archiduque ${ }^{86}$, no en vano, entre sus «militantes» más significados localizamos a uno de los hijos de doña Luisa, don Juan Lucas Carrillo Guill, regidor y familiar del Santo Oficio. Emparentado con la propia doña Luisa estará el cabecilla del partido austracista murciano, el regidor don Diego Rejón de Silva y Verástegui.

Nos encontramos ante una tertulia doméstica, convocada en la residencia de una familia de austracistas, a la que según los testigos, asistiría la propia anfitriona, sus dos hijos, don Manuel y don Juan Lucas Carillo, así como varios frailes de la orden dominica cercanos a los Macanaz, entre los que se citará a fray Gonzalo de Soria y otros como fray Antonio Mateos y fray Juan Pareja. La vinculación de estos últimos a la casa Lucas-Guill no nos es conocida, suponiendo en todo caso la conexión a través de uno de los testigos, el también dominico fray Fernando Rejón de Silva, sobrino de doña Luisa y hermanastro del líder austracista don Diego Rejón de Silva.

En la reunión, más cercana a un conventículo donde banalizar o realizar comentarios y críticas sobre los últimos rumores, será fray Gonzalo quien comunicará al resto de asistentes las noticias más destacadas de la marcha de don Melchor. Conocedor de los chismes y cábalas que circulaban en el convento sobre el destino de Macanaz, fray Gonzalo no dudará en compartirlos con el resto de asistentes. Uno de los comentarios que más interés generará en el interrogatorio de los

84. Idem, fols. $49 \mathrm{r}-49 \mathrm{v}$.

85. Declaración de fray Domingo López (...), fols. 38v-39r.

86. Sobre el austracismo murciano, vid. MuÑoz Rodríguez, J. D.: Felipe V y..., op. cit., pp. 125-139. 
inquisidores, será el relacionado con la vuelta del ex fiscal. Parece que entre los cercanos a fray Antonio el regreso de su hermano se daba por seguro, algo que el propio don Melchor contribuiría a hacer creer en su numerosa correspondencia.

Cualquier noticia que pudiera interpretarse en positivo con la suerte de Macanaz, era contemplada por los frailes desde la óptica de su inminente regreso. En este sentido, se entenderá el lógico alborozo de buena parte de la comunidad dominica tras el correo con el nombramiento de su sobrino, Juan Narciso Macanaz, de la ya comentada ración en la Catedral de Málaga. La propia contra-reforma del Consejo de Hacienda tras la derogación de la Nueva Planta (agosto de 1715), será aplaudida por fray Gonzalo al haber comprendido en ella a «todas las hechuras de Ronquillo ${ }^{87}$ o las más, contando en este numero a Pedrosa y Zeferino» ${ }^{88}$.

Crecido con tales argumentos, no es de extrañar que fray Gonzalo comentara con alguna ligereza en la tertulia aquello que le atribuirán los testigos. Entre ellos, don Juan Lucas Carrillo, quien estando de visita en casa su madre, recordará haberle preguntado a fray Gonzalo «por las noticias que tenía de dicho don Melchor Macanaz (...) y respondió diciendo, ese hombre es un diablo y escribe que volverá presto a Madrid con su empleo o cosa mejor» ${ }^{89}$. Fray Fernando Rejón de Silva, confirmará en su declaración haber sido informado de la conversación anterior, tomando por ciertas las palabras de fray Gonzalo sobre «que don Melchor Macanaz volvería muy presto a España con los honores y puestos que había tenido antes y que era tan diablo que lo conseguiría» ${ }^{90}$.

Interrogado por lo anterior, fray Gonzalo confesará no recordar donde le habían preguntado por lo referido, pero que las diferentes veces que le han «hablado de don Melchor Macanaz ha respondido, el es un diantre y sagaz y se compondrá, y esto lo ha dicho así en las conversaciones con sus amigos como en alguna casa conocida que ahora no hace memoria» ${ }^{91}$. Otro de los comentarios vertidos en la tertulia será el relativo a los dependientes que Macanaz había dejado en la corte, como Luis Sánchez Ulloa, de quien Lucas Carrillo aseguraba que fray Gonzalo le había confesado que «dicho don Melchor lo detenía en ella (...) alentándolo con la esperanza de su próxima venida» ${ }^{92}$.

87. Francisco Ronquillo y Briceño, presidente del consejo de Castilla hasta la entrada en vigor de los decretos de Nueva Planta de noviembre de 1713, será una de las autoridades más críticas con Macanaz desde sus primeros empleos confiscatorios en el reino de Valencia, vid. Martín Gaite, op. cit., pp. 159-171.

88. Declaración de fray Domingo López (...), fols. 36r-37v.

89. Declaración de Juan Lucas Carillo, regidor, celebrada el 18 de septiembre de 1715, AHN, Inquisición, leg. 3697-2, fols. 51r-51v.

90. Declaración de fray Fernando Rejón de Silva (...), fol. 41v.

91. Declaración de fray Gonzalo de Soria (...), fols. 48r-48v.

92. Idem, fol. 52r. 
La imagen de Macanaz que se tratará de difundir tanto en el convento como en la tertulia, logrará presentarlo como víctima del juego de poder establecido en torno a Felipe V. Se insistirá así en las estratagemas seguidas por sus muchos y poderosos enemigos, quienes «habían tomado el recurso de delatar el papel [«Pedimento»] para lograr por este medio apartarlo de la gracia del rey» ${ }^{93}$. Para convencerse de las posibilidades de su vuelta, se tomaba como ejemplo el caso del consejero Luis del Curiel, quien apartado del consejo de Castilla por haber filtrado al inquisidor general el texto del «Pedimento», había logrado recomponerse en su empleo tras unos meses de alejamiento. Si Curiel lo había conseguido, creían sus seguidores «sería lo mismo don Melchor y que el rey lo había mandado estuviese en Pau con su toga cobrando su renta» ${ }^{94}$.

\section{ESCARNIO Y CASTIGO: BELLUGA Y LA INQUISICIÓN CONTRA FRAY ANTONIO MACANAZ}

La situación denunciada por Belluga e investigada por la Inquisición dará como resultado el procesamiento de fray Antonio Macanaz en la primavera de 1716. Todo un escarmiento para el religioso que había sido capaz de oponerse a los reproches del obispo, aglutinando en torno a sí un destacado número de personas interesadas en las noticias de su hermano. Con el proceso de fray Antonio se conseguirá eliminar al principal referente de quien en ese momento era el anatemizado político por excelencia (Melchor Macanaz), al tiempo que sus adversarios, entre ellos el propio Belluga, se permitían devolver ahora con creces las afrentas soportadas meses atrás. Un auténtico ajuste de cuentas, fulminado de nuevo a través de la más poderosa herramienta de control político y social, la Inquisición, a la que no le costará excesivo esfuerzo localizar entre las declaraciones anteriores indicios suficientes contra fray Antonio.

La causa del religioso la conocemos a partir de diversas fuentes. A las declaraciones de los testigos ya analizadas, la consulta de una serie de cartas enviadas desde la Inquisición de Murcia al Consejo de la Suprema nos ha permitido seguir los principales acontecimientos de su arresto y prisión. La correspondencia y escritos de su hermano arrojan también valiosa información sobre el cargo y las circunstancias del dominico.

La acusación principal contra fray Antonio se reducirá a su manifiesta defensa del condenado y censurado «Pedimento Fiscal de los cincuenta y cinco puntos» ${ }^{95}$.

93. Respuesta dada por fray Antonio Macanaz al padre fray Diego López de Castilla, A. H. N. Inquisición, leg. 3697-2, fols. 32r-32v.

94. Declaración de fray Ignacio de la Portilla (...), fol. 38r.

95. Alegaciones fiscales de Fray Antonio Macanaz, A. H. N. Inquisición, leg. 3736-71, fols. $1 \mathrm{r}-1 \mathrm{v}$. 
Para don Melchor, sin embargo, el verdadero interés del inquisidor general Del Giudice -a quien responsabilizará de la causa- será el de impedir que «entrase en posesión de la plaza de consejero de Inquisición que el rey le había dado y obligado a aceptar, para lo que le puso preso el cardenal, pretestando que había dicho que el papel de su hermano (...) era muy arreglado a razón y justicia» ${ }^{96}$.

La orden de arresto se fechará el 22 de mayo de 1716. Días después, el 9 de junio, desde la Inquisición de Murcia se informará al consejo haber «prendido en conformidad la persona de fr. Antonio Macanaz (...) con la más exacta diligencia» ${ }^{97}$. La influencia de Belluga en el proceso será una constante. Dos de los tres inquisidores presentes en la causa contra el dominico -Luis Manuel Arroyo y Juan Ignacio de Alfaro- formaban parte del círculo más cercano del obispo. Naturales de la localidad sevillana de Puente Genil, Alfaro había coincidido con Belluga en el Colegio mayor de Santa María de Jesús de Sevilla, mientras que Arroyo desempeñaba funciones de confesor particular del propio obispo. Ambos seguirán ligados a la trayectoria posterior de Belluga ${ }^{98}$.

Preso ya fray Antonio, la Inquisición murciana comunicará a la Suprema el inicio de los trabajos realizados por los secretarios del secreto, Marín y Campuzano, relativos al examen, embargo y revisión de «todos los papeles con el mayor cuidado sin que quedase cosa alguna en dicha celda que no registrasen» ${ }^{99}$. El objetivo no era otro que dar con el texto que comprometiera al religioso, es decir, encontrar alguna copia o fragmento del «Pedimento». El otro interés radicaba en hallar rastro de la correspondencia que fray Antonio había mantenido en los meses posteriores a la caída de don Melchor, entre otros con su propio hermano, así como demás personas «de dentro y fuera del Reino de Murcia, como también con el Obispo de Málaga, con su provincial y otros religiosos de su Orden»100. Una tarea difícil, pues como los propios inquisidores señalarán «se reconoce la prevencion y cautela con que procedía [fray Antonio] en algunas cartas» ${ }^{101}$.

Los resultados del registro permitirán localizar al fin «un extracto de un capítulo de un papel (a que de su epígrafe llamaron gran papel) y parece se había de formar por una junta de Ministros para instruir el ánimo de S. M.» ${ }^{102}$. Junto al

96. Fragmentos de cartas y memoriales sobre la persecución de que era objeto por parte de la Inquisición, Biblioteca Histórica de Santa Cruz. Mmss. 204, fols. 21r-22r.

97. Carta de la Inquisición de Murcia al Consejo de la Suprema Inquisición, Murcia, 9 de junio de 1716, A. H. N. Inquisición, leg. 2849-1, s/f.

98. Debo estos datos a la generosidad del profesor Dr. D. Antonio Irigoyen López, quien prepara una obra sobre las redes de patrocinados y hechuras del obispo Belluga.

99. Carta de la Inquisición de Murcia al Consejo de la Suprema Inquisición, Murcia, 9 de junio de 1716, en AHN. Inquisición, leg. 2849-1, s/f.

100. Ibidem.

101. Ibidem.

102. Ibidem. 
anterior, se encontrarán dos copias de sendas cartas escritas por don Melchor; una, se identificará con la que el ex fiscal había mandado a Belluga en plena polémica por el impuesto de la sal, mientras que la otra, había sido remitida al franciscano fray Alonso Rosique, refiriendo las fuentes utilizadas en la redacción del «Pedimento». El hallazgo de estos tres documentos comprometía gravemente la defensa del propio fray Antonio, probándose buena parte de lo declarado por los testigos, en relación a haber visto al dominico «exhibir o mostrarles algunos de ellos» ${ }^{103}$.

Con el pliego de los documentos localizados en su celda, pronto comenzarán los interrogatorios al reo. Las primeras audiencias se toparán con un fray Antonio profundamente depresivo, avergonzado y humillado, cuyo estado hacía muy difícil el desarrollo del trabajo de los inquisidores. En este sentido se pronunciarán en una carta al Consejo, en la que daban cuenta de lo mucho que este religioso «lloraba, comía poco y padecía vigilia, continuándose su melancolía (...)» ${ }^{104}$. Vejado socialmente, la sensación de afrenta sentida por quien había disfrutado de «la grande estimación, aplauso o adulación que ha tenido en esta ciudad y Reino» ${ }^{105}$, consumía a fray Antonio en una de las cárceles secretas de la Inquisición local.

El deterioro físico del dominico «quebrantado por la flaqueza y palidez del rostro» también preocupaba. En más de una ocasión se le había sugerido la visita de un médico, ofrecimiento que era rechazado continuamente por el procesado. Tal será la situación de angustia vivida durante estas semanas, que los propios inquisidores se temían que pudiera caer «en alguna profunda melancolía o demencia» ${ }^{106}$. En carta de 7 de julio, se informaba desde la Inquisición de Murcia de los pocos progresos en la averiguación de la causa. El reo solo manifestaba su desazón y voluntad para que «se le pusiera para toda su vida donde no le vieran gentes», lamentándose que ya «no es lo que era, ni es nada» ${ }^{107}$.

A principios de septiembre de 1716 se había comunicado ya a fray Antonio la acusación que pesaba sobre él. Desde entonces, parece que se había logado cierto avance en el interrogatorio, empeño que seguía viéndose dificultado por la lentitud y dilación con la que contestaba a las cuestiones formuladas. Esta tardanza llevará a plantear a los inquisidores la posibilidad de limitar las respuestas de fray Antonio, propuesta que será negada por la Suprema, ordenando «le dejen decir y dictar todo lo que quisiere sin interrumpirle ni advertirle cosa para que en ningun

103. Ibidem.

104. Carta de la Inquisición de Murcia al Consejo de la Suprema Inquisición, Murcia, 23 de junio de 1716, en AHN. Inquisición, leg. 2849-1, s/f.

105. Ibidem.

106. Ibidem.

107. Carta de la Inquisición de Murcia al Consejo de la Suprema Inquisición, Murcia, 7 de julio de 1716, en AHN, Inquisición, leg. 2849-1, s/f. 
caso tenga el voluntario motivo de quejarse que le quitan la libertad» ${ }^{108}$. En sus respuestas, carentes de originalidad, fray Antonio insistía «no haber visto el papel de don Melchor Macanaz, antes ni después de la prohibición» ${ }^{109}$.

En esta situación se encontraba el proceso cuando en abril de 1717, una denuncia efectuada por don José Sanz de Lizondo, alcaide de la cárcel del Santo Oficio murciano, ponía en aviso a los inquisidores sobre la comunicación que el teniente de alcaide, don Francisco García Conde, permitía mantener al reo Macanaz con «noticias de novedades y cosas ocurrentes por fuera» ${ }^{110}$. El «modus operandi» de García Conde consistía en utilizar a una de sus criadas, una tal Magdalena de Guzmán (que asistía a fray Antonio), para facilitarle cartas y transmitirle los rumores sobre su causa.

Un repentino ataque de catalepsia sufrido al poco de iniciarse las pesquisas de la Inquisición para aclarar la denuncia, retrasará durante varios meses la declaración del teniente de alcaide. En el mes de junio, ya recuperado, García Conde reconocerá a los inquisidores que fray Antonio «le habia ganado con esperanzas de verse todavía en la plaza del Consejo y entonces procurarle sus maiores conveniencias», afirmando que la comunicación permitida o tolerada fue en «orden a su importante dependencia y a lograr acerca de ella correspondencia y comunicación» ${ }^{111}$.

Los problemas de seguridad y la dificultad para retener incomunicado a fray Antonio en Murcia, motivarán su traslado a la Inquisición de Cuenca ${ }^{112}$. El 11 de mayo se informaba desde la Inquisición murciana sobre la ejecución del mandato:

se entregó dicho fray Antonio Macanaz con el proceso de su causa cerrado y sellado a don Fco. Arias de Castro comisario y cura propio en la villa de Jumilla de quien hacemos entera confianza para dicho efecto y en su compañía van don Thomas Arias presbítero, su sobrino, don Juan Antonio de Sierra y don Andrés Campoy y dos guardias de a pie de la confianza de dicho Comisario, vecinos de Jumilla (...) y la entrega fue el día 7 del corriente a las doce de la noche ${ }^{113}$.

108. Respuesta del Consejo de la Suprema a la Inquisición de Murcia, en AHN, Inquisición, leg. 2849-1, s/f.

109. Carta de la Inquisición de Murcia al Consejo de la Suprema Inquisición, Murcia, 7 de septiembre de 1716, en AHN, Inquisición, leg. 2849-1, s/f.

110. Carta de la Inquisición de Murcia al Consejo de la Suprema Inquisición, Murcia, [...], abril de 1717, en AHN, Inquisición, leg. 2850-1, s/f.

111. Carta de la Inquisición de Murcia al Consejo de la Suprema Inquisición, Murcia, 28 de junio de 1717, en AHN, Inquisición, leg. 2850-1, s/f.

112. Respuesta del Consejo de la Suprema a la Inquisición de Murcia, 20 de abril de 1717, en AHN, Inquisición, leg. 2850-1, s/f.

113. Carta de la Inquisición de Murcia al Consejo de la Suprema Inquisición, Murcia, 11 de mayo de 1717, en AHN, Inquisición, leg. 2850-1, s/f. 
En Cuenca pasará fray Antonio la parte final de su condena. Don Melchor nos informará de ello en una carta escrita en defensa de su hermano, en la que denunciaba el modo con el que «logró el Cardenal [Del Giudice] que los ministros del Consejo, todos hechuras suyas, le condenase en un año de reclusión y tres de destierro de Murcia y esta corte» ${ }^{114}$. Superado el término de la pena, parece que en 1720 fray Antonio vivía ya en el convento de Santo Domingo de la ciudad de Baza, en una especie de «libertad vigilada», tutelada por una Inquisición que seguía muy de cerca la posible comunicación con su hermano ${ }^{115}$. Allí volverá a coincidir con su amigo Marín Blázquez, ahora corregidor de la plaza granadina ${ }^{116}$, donde permanecerá fray Antonio hasta su fallecimiento mediada la década de $1750^{117}$.

\section{Conclusiones}

El estudio del proceso contra fray Antonio nos ha permitido dar con sendas realidades no institucionalizadas, surgidas desde «abajo», como expresión del interés por conocer y conjeturar sobre el momento político. Tal será la corriente de opinión que logrará cuajar entre numerosos religiosos del convento murciano de Santo Domingo, así como la tertulia familiar que servirá de cauce para la circulación de buena parte de las imágenes y representaciones construidas en aquel.

Parcialidad y tertulia, reflejo a su vez del grado de intensidad con el que parte de la ciudad de Murcia seguirá los acontecimientos que precipitarán la caída del fiscal general Macanaz. Frailes y seglares mediatizados por la actuación de fray Antonio, quien sabrá labrar y mantener un grupo de partidarios e interesados en la suerte de su hermano. Su labor consistirá en trazar un discurso propio, una interpretación de los hechos que permitiera presentar a don Melchor como la víctima de una operación o maniobra política impulsada por sus enemigos. Este propósito tropezará con las trabas y resistencias del obispo Belluga, en una pugna que parece reproducir a escala local, el enfrentamiento mantenido cerca del rey entre los grupos que se disputaban el poder.

Elemento fundamental en la configuración y mantenimiento del colectivo afín a fray Antonio será la circulación de información. Tránsito de cartas, textos y memoriales que se intercambian y leen, ayudando con ello a transmitir el discurso que se pretende. Un sistema de comunicación articulado por un buen número de complicidades que permitirán mantener en contacto a un prófugo de la Inquisición

114. Memorial sobre fray Antonio escrito por don Melchor Macanaz (s/l, 27 de junio de 1720), en BAM Mmss. 912-21, s/f.

115. Martín Gaite, op. cit., pp. 369-370.

116. Muñoz Rodríguez, J. D.: Felipe V y..., op. cit., p. 265.

117. Referencia recogida en la declaración de uno de los últimos criados de Melchor Macanaz. Memoria de don Gerónimo de Urdinarana (1794), en BAM, Mmss. 740-V-3, s/f. 
con su círculo más cercano, objetivo para el que se implicarán familiares, amigos y hasta ciertas autoridades como el corregidor Marín Blázquez.

El fenómeno de comunicación y socialización de lo político, estudiado a partir del caso de los hermanos Macanaz, nos ha conducido a un escenario de relativa complejidad. El doble ejemplo de la tertulia sirve para ilustrar, por un lado, la aparente paradoja que supondrá la presencia de frailes cercanos a los Macanaz (cuya lealtad a la nueva dinastía queda fuera de duda) en las reuniones políticas celebradas en casa de una familia de austracistas murcianos. Por otro, la coincidencia en el procesamiento de fray Antonio de un borbónico declarado, como el obispo Belluga, y austracistas como los Rejón de Silva y Lucas Carrillo. A nuestro juicio, todo ello no hace más que revelar la existencia de ciertos intereses y espacios compartidos, en el que los lazos y las relaciones personales se superponen a la rigidez de los modelos definidos por la historiografía tradicional. Austracistas y borbones colaborando en la construcción de un espacio político común, definido por individuos, grupos y familias cuyas redes y trayectorias señalan -como afirma García Cárcel- el camino de los matices ${ }^{118}$. Ejemplos como los anteriores, difíciles de encajar, pueden ayudar a descubrir la gama intermedia entre el blanco y el negro, la tonalidad que enriquezca la serie de comportamientos y actitudes varias que dominaron la escena política local y territorial en los años iniciales del reinado de Felipe V.

\section{BibliografíA}

Abellán, J. L.: Historia crítica del pensamiento español, vol. III. Madrid, 1981.

Alabrús Iglesies, R. M. ${ }^{a}$ : «La trayectoria de la opinión política en la España moderna», Obradoiro de Historia Moderna, 20, 2011, pp. 337-338.

Álvarez de Morales, A.: La ilustración y la reforma de la Universidad en la España del siglo XVIII. Madrid, 1988.

BARrio Gozalo, M.: «El clero bajo sospecha a principios del siglo xviII. El informe de Macanaz y la respuesta de los obispos», Investigaciones históricas, 22, 2002, pp. 55-56.

Bernardo Ares, J. M. de: «Felipe V: La transformación de un sistema de gobierno», en Serrano Martín, E. (ed.): Felipe V y su tiempo. Congreso Internacional, vol. I. Zaragoza, 2004, pp. 967-990.

Bouza Álvarez, F. J.: Corre manuscrito: Una historia cultural del Siglo de Oro. Madrid, 2001.

Cano Valero, J:: Rafael Melchor de Macanaz. Político y diplomático ilustrado. Albacete, 2008.

118 García Cárcel, R.: «Fin de siglo, fin de dinastía. Algunas reflexiones», Estudis: Revista de Historia Moderna, 31, 2005, pp. 67-81, en espec. pp. 80-81. 
Carabias Torres, A. M.a : « ¿La muerte del letrado? Consideraciones sobre la tipología del oficial español en el siglo xviıı», en Dios de Dios, S. y Torijano, E. (coords.): Cultura politica y práctica del derecho. Juristas de Salamanca, siglos XV-XX. Salamanca, 2012, pp. 143-238.

Carasa Soto, P.: «De la teoría de las élites a la historia de las élites», en Chacón Jiménez, F. y Hernández Franco, J. (eds.): Espacios sociales, universos familiares. La familia en la historiografía española. Murcia, 2007, pp. 93-95.

Castillo Gómez, A. y Amelang, J. (coords.): Opinión pública y espacio urbano en la Edad Moderna. Madrid, 2010.

Castro Monsalve, C. de: «La Nueva Planta del Consejo de Castilla y los pedimentos de Macanaz», Cuadernos de Historia Moderna, 37, 2012, pp. 35-37. <http://dx.doi. org/10.5209/rev_CHMO.2012.v37.39226>.

Coronas González, S. M.: Ilustración y Derecho. Los fiscales del Consejo de Castilla en el siglo XVIII. Madrid, 1992.

Dedieu, J.-P.: «La nueva planta en su contexto. Las reformas del aparato del Estado en el reinado de Felipe V», Manuscrits, 18, 2000, pp. 118-121.

Dedieu, J.-P.: «La muerte del letrado», en Aranda Pérez, J. F. (coord.): Letrados, juristas y burócratas en la España Moderna. Cuenca, 2005, pp. 479-511.

Dedieu, J.-P: «El aparato de gobierno de la monarquía española en el siglo XviII», en Pérez Sarrión, G. (coord.): Más Estado y más mercado: absolutismo y economía en la España del siglo XVIII. Madrid, 2011, pp. 53-74.

Écija Rioja, M.: Tercer centenario del Memorial antirregalista del cardenal Belluga a Felipe V: un conflicto jurídico entre Iglesia y Estado en 1709. Murcia, 2010.

Egido López, T.: Sátiras politicas en la España Moderna, I-II. Madrid, 1973.

EGIDo López, T.: «El regalismo y las relaciones Iglesia-Estado en el siglo XVIII», en Mestre Sanchís, A. (dir.): La Iglesia en la España de los siglos XVII y XVIII. Madrid, 1979, pp. 125-254.

Egido López, T.: «Las reformas fracasadas. El significado de Macanaz», en Villanueva Pérez J., Escandell Bonet, B. y Alcalá, A. (dirs.): Historia de la Inquisición en España y América, vol. I. Madrid, 1984, pp. 1234-1247.

EgIdo López, T.: Opinión pública y oposición al poder en la España del siglo XVIII (17131759). $2^{\text {a }}$ edición. Valladolid, 2002.

Egido López, T.: «El discurso teologizante del antirregalismo (1709)», en Serrano Martín, E. (ed.): Felipe V y su tiempo. Congreso Internacional, vol. I. Zaragoza, 2004, pp. 925-932.

Enciso Recio, L. M., «Prensa y opinión pública», en VV. AA.: La época de los primeros Borbones. La cultura española entre el Barroco y la Ilustración (1700-1759), vol. II. Historia de España-Menéndez Pidal, tomo XXIX. Madrid, 1985, pp. 197-258.

Enciso Recio, L. M.: «Los mensajes de la opinión pública y la propaganda en la España Moderna», en VV. AA.: Propaganda y opinión pública en la Historia. Valladolid, 2007, pp. 49-90.

Escudero, J. A.: «La reconstrucción de la administración central en el siglo XVIII», en VV. AA.: La época de los primeros Borbones. La cultura española entre el Barroco y 
la Ilustracion (1700-1759), vol. I. Historia de España-Menéndez Pidal, tomo XXIX. Madrid, 1985, pp. 81-175.

Fayard, J.: «La tentative de réforme du Conseil de Castille sous le règne de Philippe V (1713-1715)», Mélanges de la Casa de Velázquez, t. II, 1966, pp. 259-282.

Franco Rubio, G.: «El ejercicio del poder en la España del siglo xviII. Entre las prácticas culturales y las prácticas políticas», Mélanges de la Casa de Velázquez, 35,1, 2005, pp. 51-78.

García CÁrcel, R.: «Fin de siglo, fin de dinastía. Algunas reflexiones», Estudis: Revista de Historia Moderna, 31, 2005, pp. 67-81.

García García, B. J.: «Sátira política a la privanza del duque de Lerma», en Guillamón Álvarez, F. J. y Ruíz Ibáñez, J. J.: Lo conflictivo y lo consensual en Castilla: sociedad y poder politico, 1521-1715: bomenaje a Francisco Tomas y Valiente. Murcia, 2001, pp. 261-298.

Gastón PÉrez, J. (ed.): La rebelión de las palabras. Sátiras y oposición politica en Aragón (1590-1626). Zaragoza, 2003.

GiL Pujol, X.: «Notas sobre el estudio del poder como una nueva valoración de la historia política», Pedralbes, 3, 1983, pp. 61-88.

GIL Pujol, X.: «La historia política de la Edad Moderna, hoy: progresos y minimalismo», en Barrios, C. (coord.): Historia a debate, vol. III. Santiago de Compostela, 1995, pp. 195-196.

Guillamón Álvarez, F. J.: «El estudio del conflicto y del consenso desde una perspectiva integradora», en Guillamón Álvarez, F. J. y Ruíz IbáñEz, J. J.: Lo conflictivo y lo consensual en Castilla: sociedad y poder politico, 1521-1715: homenaje a Francisco Tomás y Valiente. Murcia, 2001, pp. 13-24.

Hernández Franco, J. y Precioso Izquierdo, F.: «Discursos enfrentados en los albores de la Monarquía borbónica. Reacciones al Pedimento Fiscal de Macanaz», Mediterranea-ricerche storiche, 30, 2014, pp. 77-82.

Irigoyen López, A.: Un Obispo, una Diócesis, un clero: Luís Belluga, prelado de Cartagena. Murcia, 2005.

Losa Serrano, P. y López Campillo, R. M.a: «La Guerra de Sucesión española y la opinión pública inglesa», en García González, F. (coord.): La Guerra de Sucesión en España y la Batalla de Almansa. Europa en la Encrucijada. Madrid, 2007, pp. 133-138.

Maldonado Macanaz, J.: Melchor de Macanaz. Testamento politico. Pedimento fiscal (edición y notas por Francisco Maldonado de Guevara). Madrid, 1972.

Martín Gaite, C.: Macanaz, otro paciente de la Inquisición. Barcelona, 1982.

Martín Marcos, D.: El Papado y la Guerra de Sucesión española. Madrid, 2011.

Martín Martínez, I.: «Fundamentos doctrinales e históricos de la posición antirregalista del cardenal Belluga», en Cremades Griñán, C. M.a: Estudios sobre el Cardenal Belluga. Murcia, 1985, pp. 59-83.

Martínez Ripoll, A.: «Regalismo borbónico, reformismo eclesiástico y relaciones con Roma: el cardenal Belluga», en Contreras, J., Alvar, A. y Ruíz, J. I.: Política y cultura 
FRAY ANTONIO MACANAZ Y EL OBISPO BELLUGA (1714-1720)

en la época moderna: Cambios dinásticos, milenarismos, mesianismos y utopias. Madrid, 2004.

Mestre Sanchís, A.: «La Iglesia y el Estado. Los concordatos de 1737 y 1753», en VV. AA.: La época de los primeros Borbones. La cultura española entre el Barroco y la Ilustración. (1700-1759), vol. I, Historia de España-Menéndez Pidal, tomo XXIX. Madrid, 1985, pp. 283-300.

Mestre Sanchís, A.: «La actitud religiosa de los católicos ilustrados», en Guimerá, A. (ed.): El reformismo borbónico. Una visión interdisciplinar. Madrid, 1996, pp. 147-163.

Mestre Sanchís, A.: «Nueva dinastía e Iglesia nacional» en Fernández Albaladejo, P.: Borbones. Dinastia y memoria de nacion en la España del siglo XVIII. Madrid, 2002, pp. 549-567.

MuÑoz Rodríguez, J. D.: Felipe $V$ y cien mil murcianos más. Movilización social y cambio político en la Corona de Castilla durante la Guerra de Sucesión (1680-1725), Tesis Doctoral. Universidad de Murcia, 2010.

Olivari, M.: Avisos, pasquines y rumores. Los comienzos de la opinión pública en la España del siglo XVII. Madrid, 2014.

Peña IzQuierdo, A. R.: La crisis sucesoria de la Monarquía española. El cardenal Portocarrero y el primer gobierno de Felipe V, vol. I, Tesis Doctoral. Universidad Autónoma de Barcelona, 2005.

Pérez Magallón, J.: Construyendo la modernidad: la cultura española en el tiempo de los novatores (1675-1725). Madrid, 2002.

Pérez Picazo, Ma . T.: La publicística española en la Guerra de Sucesión, vol. I-II. Madrid, 1966.

Peset, M. y Peset, J. L.: La universidad española (siglos XVIII y XIX): despotismo ilustrado y revolución liberal. Madrid, 1974.

Precioso Izquierdo, F.: «Encubrimiento familiar, proyección política: Los Macanaz (1630-1700)», Chronica Nova, no 38, 2012, pp. 203-220.

Precioso Izquierdo, F.: «El beneficio de la fidelidad: Melchor Macanaz y la casa de Villena (1694-1706)», en Martínez Millán, J., Camarero, C. y Luzzi, M. (coords.): La corte de los Borbones: crisis del modelo cortesano. Madrid, 2013, pp. 1163-1181.

Remond, R.: Pour une histoire politique. París, 1983.

Remond, R.: El Antiguo Régimen y la Revolución. 1750-1815. Barcelona, 1983.

STORrs, C.: La resistencia de la Monarquía Hispánica (1665-1700). Madrid, 2013.

Vallejo García-Hevia, J. M.a: «Macanaz y su propuesta de reforma del Santo Oficio de 1714», Revista de Inquisición, 5, 1996, pp. 218- 327.

Velasco Moreno, E.: La Real Academia de la Historia en el siglo XVIII: una institución de sociabilidad. Madrid, 2000.

Vicent López, M. I.: «La cultura política castellana durante la Guerra de Sucesión», en Fernández Albaladejo, P.: Los Borbones. Dinastía y memoria de nación en la España del siglo XVIII. Madrid, 2002, pp. 225-232.

VILAR, J. B.: El cardenal Luis Belluga, Granada, 2005.

Zamora, A.: Historia de la Real Academia Española. Madrid, 1999. 